\title{
DNA intensity and genetic diversity of oil palm (Elaeis guineensis) to determine an elite low lipase line
}

\author{
NINA UNZILA ANGKAT ${ }^{1}$, LUTHFI AZIZ MAHMUD SIREGAR ${ }^{2,4}$, MOHAMMAD BASYUNI $^{3,4}$, \\ DADANG AFANDI ${ }^{1}$, INDRA SYAHPUTRA ${ }^{5}$ \\ ${ }^{1}$ Graduate Program of Agrotechnology, Faculty of Agriculture, Universitas Sumatera Utara. Jl. Prof. A. Sofyan No. 3 Medan, 20155, North Sumatra, \\ Indonesia \\ ${ }^{2}$ Department of Agrotechnology, Faculty of Agriculture, Universitas Sumatera Utara. J1. Prof. A. Sofyan No. 3 Medan, 20155, North Sumatra, Indonesia. \\ Tel.: +61-8213236, vemail: luthfi1@usu.ac.id, luthfi2004@yahoo.com \\ ${ }^{3}$ Department of Forestry, Faculty of Forestry, Universitas Sumatera Utara. Jl. Tri Dharma Ujung No. 1, Medan, 20155, North Sumatra, Indonesia \\ ${ }^{4}$ Mangrove and Bio-Resources Group, Center of Excellence for Natural Resources Based Technology, Universitas Sumatra Utara. Medan 20155, \\ North Sumatra 20155, Indonesia \\ ${ }^{5}$ PT. Socfin Indonesia. Jl. KL Yos Sudarso No. 106, Medan 20115, North Sumatra, Indonesia
}

Manuscript received: 7 October 2020. Revision accepted: 20 January 2021.

\begin{abstract}
Angkat NU, Siregar LAM, Basyuni M, Afandi D, Syahputra I. 2021. DNA intensity and genetic diversity of oil palm (Elaeis guineensis) to determine an elite low lipase line. Biodiversitas 22: 900-905. The acidification of palm oil due to lipase activity in the mesocarp is assessed under genetic control. Three molecular markers have been established to gauge the lipase gene in oil palm. Lower lipase activity is desired for good quality edible oil. This study aims to identify the genetic diversity by screening groups/families to determine an elite low lipase genotype of oil palm. Genetic diversity and population structure of 15 groups of oil palm were investigated by using three specific markers with GenAlex 6.502 software. Results show that the Polymorphic Informative Content (PIC) value of markers was around 0,985-0,993, which indicates that these markers are effective in determining the diversity of lipase activity in oil palm. Analysis of molecular variance (AMOVA) revealed that genetic diversity varies within individuals (54\%), among individuals $(31 \%)$, and among population (15\%). The value of number of alleles $(\mathrm{Na})$, number of effective alleles $(\mathrm{Ne})$, observed heterozygosity $(\mathrm{Ho})$, expected heterozygosity $(\mathrm{He})$, and number of allele migration $(\mathrm{Nm})$ indicate that the genetic diversity in this population is relatively low. Phylogenetic analysis identified two main groups as high lipase and low lipase activity groups based on DNA intensity.
\end{abstract}

Keywords: AMOVA, lipase, microsatellite, oil palm

\section{INTRODUCTION}

Oil palm is the most important edible oil globally (Singh et al. 2013). According to the United States Department of Agriculture (2019), Indonesia is one of the largest producers and exporter of palm oil globally, producing a total of 43 million tons in 2019. Globally, the total vegetable oil production was 207.06 million MT, of which palm oil is the highest (75.69 million MT or 36.6\%), followed by soybean oil (56.73 Million MT) and rapeseed oil (27.04 Million MT). The quality of crude palm is extremely important in commerce. According to Indonesia National Standard SNI (2006), the maximum quality requirements of $\mathrm{CPO}$ are dirt count, free fatty acid, moisture at $0.5 \%$, and Iodine number at 55 grams Iodine per 100 grams.

The quality of palm oil can be influenced by harvest and postharvest activities, including storage time and processing delay time. The nature of raw materials and palm oil is closely related to quality components such as free fatty acid (FFA) content (Sharif et al. 2017; Oettli et al. 2018). Nonetheless, studies have confirmed that FFA formation is strongly affected by endogenous lipase under genetic control (Sambhantamurthi et al. 2000; Morcillo et al. 2013; Wong et al. 2015; Domonhedo et al. 2018). Previous studies demonstrated that a FLL1 gene in oil palm has been established as a mesocarp lipase regulating gene (Nurniwalis et al. 2017). Genes encoded lipase activity were mostly observed in ripening fruit with high acidity and lacked genotype with low acidity (Morcillo et al. 2013). Lipase plays an important role in catalyzing biochemical reactions such as esterification, interesterification, and transesterification in nonaqueous media. Incomplete hydrolysis of triglycerides results in monoacylglycerol release into diacylglycerols, increasing free fatty acid content (Singh and Sanjay 2013).

The efforts have been studied as alternative ways to control acidity. The utilization of bleaching earth adsorbent, synthetic magnesium silicate, and magnesium oxide $(\mathrm{MgO})$ has not shown significant reduction of diacylglycerol and free fatty acid levels in CPO within or without vacuum (Bariyah et al. 2017). The cost-refining process can help remove free fatty acid, but diglycerol still remains, and fatty acid becomes more susceptible to peroxidation that is a trigger to produce aldehydes and ketone responsible for rancidity (Corley and Tinker 2016; Likeng et al. 2017).

In the perennial characteristic and long life cycle of oil palm cultivation, conventional breeding might need more space and time (Cardona et al. 2018) to select promising crosses especially when increasing parental biodiversity (Herrero et al. 2020). Therefore, an effective way to screen 
oil palm lines is to determine if enzyme lipase is present in its DNA via microsatellite marker. Microsatellites or simple sequence repeats (SSRs) are widely used in genetic map construction, genetic diversity assessment, quantitative trait loci (QTL) mapping, and genetic structure determination (Ge et al. 2019; Yoichi et al. 2016). It has been used to identify plant genotype in the last 20 years due to its very informative and reproducible multi-allelic genetic marker (Mason 2015), and to evaluate oil palm genetic diversity and population structures of breeding materials and parental lines (Thongthawee et al. 2010; Okoye et al. 2016). The three validated SSR markers detect the presence of lipase activity (Domonhedo et al. 2018) and allow the breeders to screen the low and high lipase genotype of oil palm. The present study aims to identify the genetic diversity of oil palm group and examine the oil palm genotypes as a desirable elite of oil palm with a microsatellite marker synchronized to oil palm estimated characterization by CIRAD.

\section{MATERIALS AND METHODS}

\section{Study area}

This study was conducted from August 2019 to March 2020 with a sample of oil palm leaf collected from progeny trial field of E. guineensis which is grown in Aek Loba, Asahan District, North Sumatra Province, Indonesia. There are 45 genotypes from 15 different oil palm groups/families as derived from a cross between low lipase line $\mathrm{x}$ high lipase line by CIRAD. CIRAD has distinguished oil palm groups into three characters - low, moderate and high lipase - by their origin (Table 1). Leaflet samples were used for DNA isolation for molecular analysis at DNA Molecular Laboratory of Socfin Indonesia, Dolok Masihul, Indonesia.

\section{The DNA extraction}

Total DNA samples from fresh leaflets were isolated using CTAB (Cetyl Trimethyl Ammonium Bromide) method Orozco-Castillo (1994) with PVPP (Polivynilpolypirrolidone) modification method. The quality and quantity of isolated DNA were evaluated using $2 \%$ agarose gels on UV-illuminator documented using Gel Doc and by spectrophotometer method using wavelengths ( $\lambda$ ) 260/280 nm. Product PCR molecule fragment size was analyzed by UVITEC Cambridge FineReader with 50 bp DNA ladder standard.

\section{PCR amplification and visualization}

Detection of DNA target to lipase activity in oil palm was expressed by 3 validated markers from a previous study (Domonhedo et al. 2018). They were mEgCIR_LIP03, mEgCIR_LIP07, and DelEgCIR_C1E3 shown in Table 2. Every PCR reaction consists of $3 \mu \mathrm{l}$ DNA template with Mix PCR $(1 \mu$ l buffer PCR 10x; $0,3 \mu$ l $\mathrm{MgCl}_{2} ; 0,5 \mu \mathrm{l}$ primer forward; $0,5 \mu \mathrm{l}$ primer reverse; 3,7 $\mu \mathrm{l}$ $\mathrm{ddH}_{2} \mathrm{O} ; 0,2 \mu \mathrm{l}$ U Taq DNA polymerase dan 0,8 dNTPS). The PCR program for both mEgCIRLIP03 and mEgCIRLIP07 was initial pre-denaturation stage at $95^{\circ} \mathrm{C}$ for 10 mins followed by denaturation stage at $94^{\circ} \mathrm{C}$ for $30 \mathrm{~s}$. The annealing stage was at $55^{\circ} \mathrm{C}$ for $1 \mathrm{~min} 15 \mathrm{~s}$, the extension stage was at $72^{\circ} \mathrm{C}$ for $1 \mathrm{~min} 30 \mathrm{~s}$, and the final extension stage was at $72^{\circ} \mathrm{C}$ for 30 mins. The process was run with 35 cycles. Primer DelEgCIR_C1E3 was by predenaturation stage at $94^{\circ} \mathrm{C}$ for 4 mins. 10 "touchdown" cycles of denaturation stage were at $94^{\circ} \mathrm{C}$ for $45 \mathrm{~s}$. The annealing stage was at $55^{\circ} \mathrm{C}\left(-0,5^{\circ} \mathrm{C}\right.$ per cycle $)$ for $1 \mathrm{~min}$ while the extension stage was at $72^{\circ} \mathrm{C}$ for $1 \mathrm{~min}$. This was followed by 25 cycles of denaturation at $94^{\circ} \mathrm{C}$ for $45 \mathrm{~s}$, extension stage at $72^{\circ} \mathrm{C}$ for $60 \mathrm{~s}$, and final extension at $72^{\circ} \mathrm{C}$ for 30 mins (Domonhedo et al. 2018).

PCR products were expressed by $2 \%$ gel electrophoresis in $375 \mathrm{~mL}$ TAE buffer, stained with GelRed $_{\mathrm{TM}}$ for visualization. Every $3 \mu \mathrm{L}$ DNA was mixed with $2 \mu 1$ loading dye. Electrophoresis was carried out at 70 Volts for 70 mins and $50 \mathrm{bp}$ DNA ladder was used as the fragment size standard. The DNA was documented with UV-transilluminator (UV-Doc) and Gel-Doc (U Doc).

Table 1. Estimated character of oil palm based on the origin by CIRAD

\begin{tabular}{cc}
\hline Group/family & Character estimated \\
\hline PLL010 & High lipase \\
PLL045 & High lipase \\
PLL796 & High lipase \\
PLL210 & High lipase \\
PLL444 & High lipase \\
PLL682 & High lipase \\
PLL993 & Moderate \\
PLL737 & Moderate \\
PLL133 & Moderate \\
PLL507 & Moderate \\
PLL157 & High lipase \\
PLL181 & Low lipase \\
PLL966 & Low lipase \\
PLL260 & Low lipase \\
PLL233 & Low lipase \\
\hline
\end{tabular}

Source: CIRAD (unpublished data)

Table 2. Characteristic of molecular markers for lipase activity in oil palm

\begin{tabular}{clcc}
\hline \multicolumn{1}{c}{ Primer } & \multicolumn{1}{c}{ Primer sequence } & Reference allele size & Source \\
\hline mEgCIRLIP03 & F:TCAAAGAAACTTGTAGCATATATCAAA & 272 & Domonhedo et al. \\
& R:CATCCAGTAAGCTAACACACAAATG & & $(2018)$ \\
mEgCIRLIP07 & F:CAATCCCTCTCCCATTCTCA & 206 & \\
DelEgCIRC1E3 & R:CAGTGGAGCCGCTAATCTCT & \multirow{2}{*}{311} \\
& F:GCCAGATCGATCAAGCAAAT & & \\
& R:CTTTGCCAAAAGAAATGCAA & & \\
\hline
\end{tabular}




\section{Molecular data analysis}

Genetic diversity parameters were estimated using GenAlEx 6.5 such as effective number of alleles $(\mathrm{Ne})$, number of different allele frequencies (Na), nonrandomating coefficient (Fis), inbreeding coefficient (Fit), coefficient of differentiation (Fst), and total migrants (Nm). The polymorphism for each population and locus was assessed by calculating the observed average heterozygosity (Ho) and expected heterozygosity (He) (Nei 1978). Analysis of molecular variance (AMOVA) was calculated using GenAlEx version 6.3 (Peakall and Smouse 2012).

\section{DNA intensity analysis}

The DNA band profile resulted by all different markers have measured the intensity of bands (as a predicted expression) using Gel Analyzer 2010 and scored according to above of average as (1) and below-average as (0) to collect a binary matrix to put on cluster analysis (Afandi et al. 2018).

\section{Dendrogram}

Genetic distance was constructed using (Unweighted Pair Group Method using Arithmetic Average) UPGMA implemented in Multivariate Statistical Package (MVSP) ver 3.2 software to identify the phylogenetic relationship (Basyuni et al. 2018). Two dendrograms were constructed. The first one was to identify the phylogenetic of 45 total palms, and the other one was to identify phylogenetic of 15 groups.

\section{RESULTS AND DISCUSSION}

\section{DNA expression}

The expression of the DNA band profile in gel agarose was shown in all samples and has been categorized as low, moderate, and high lipase (Figure 1). Our study shows that samples 33-36 and 43-45 were found to be high lipase, 4042 were low lipase, and 37-39 were moderate lipase. It was observed that the lipase gene was exclusively expressed in all mature oil palm.

To obtain more evidence of lipase genes in oil palm, a semi-quantitative approach was taken to significantly determine an elite low lipase genotype among the population. We measured DNA intensity using Gen Analyzer software based on gene expression from the presented band visualization (Figure 2).

DNA intensity measurement by Gel Analyzer was to show the difference between genotypes. Intensity value of DNA varies based on their characterization. The intensity of DNA in mEgCIRLIP03 shows that low lipase genotype was dominated with high value of DNA intensity followed by moderate lipase genotype while high lipase genotype has lower DNA intensity.

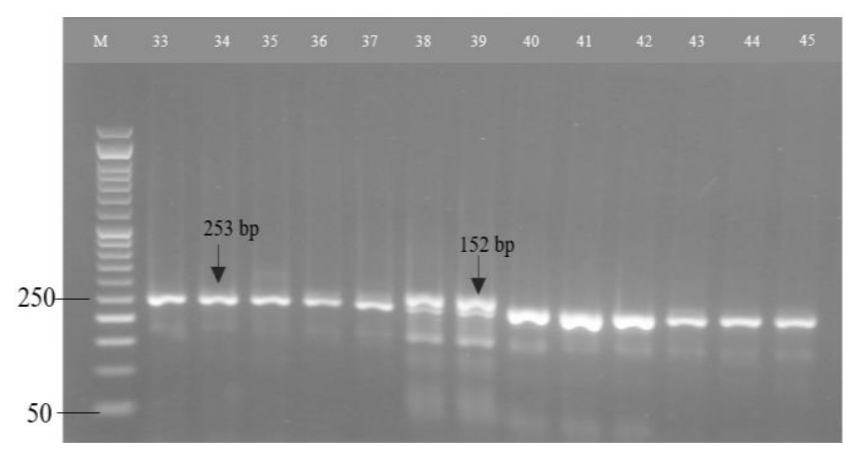

Figure 1. DNA visualization using marker mEgCIRLIP03 on agarose gel. M: DNA Ladder; 33-45: number of samples

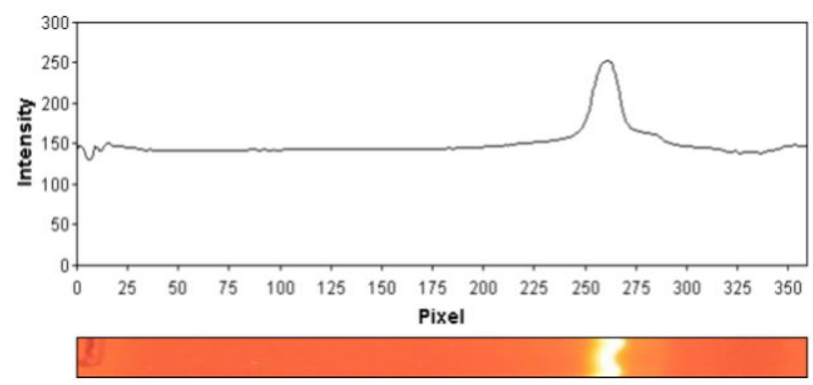

A
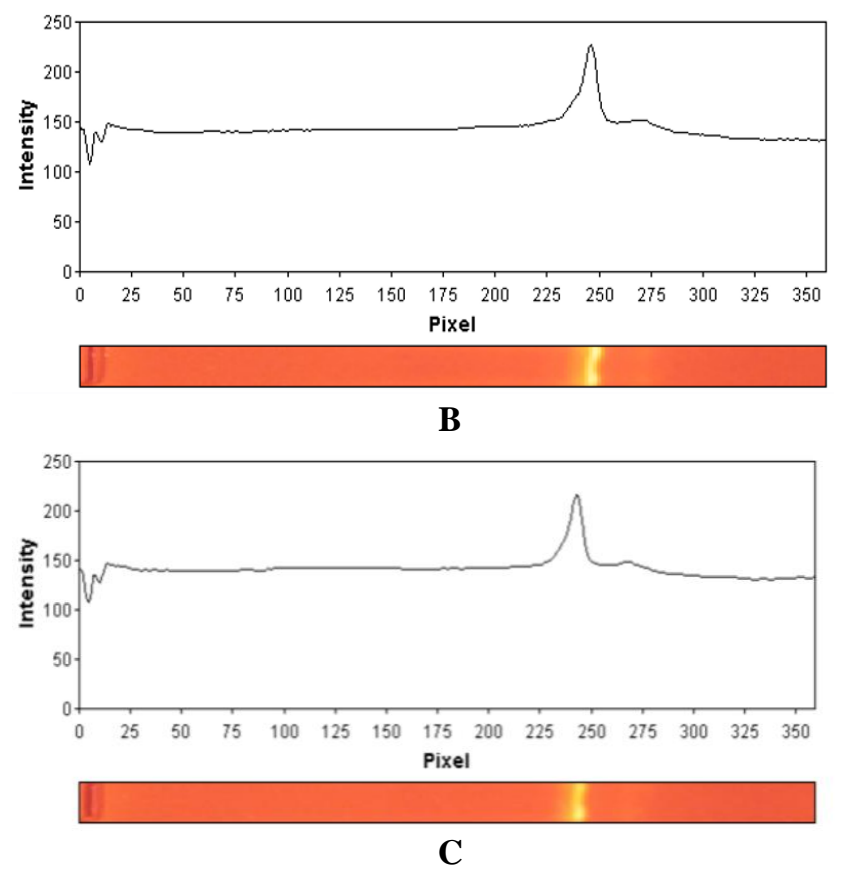

Figure 2. The intensity of DNA in mEgCIRLIP03 marker in sample 41 (A) samples 37 (B), sample 44 (C)

\section{Polymorphism markers of oil palm}

All the 45 genotypes were evaluated with 3 SSR markers loci resulting in various alleles about 22-36 and the average was 30.77 allele per locus (Table 3.). Total of 45 genotypes from 15 groups of oil palm was identified in three specific loci (mEgCIRLIP_03, mEgCIR_LIP_07, DeLEgCIR_C1E3). The PIC value (polymorphic 
information content) of each markers respectively are mEgCIRLIP07 (0.985), DelEgCIRC1E3 (0.990), mEgCIRLIP03 (0.993). The total number of alleles determined the PIC value of each marker and the frequency of distribution within a population, wherein high PIC was $>$ 0.5 , moderate $0.5>\mathrm{PIC}>0.25$, and low $\mathrm{PIC}$ was $<0.25$ (Bhattacharya et al. 2010).

Furthermore, these markers could be useful for genetic mapping according to Roubos et al. (2010) that PIC > 0.7 . The probability (PI) in this study is lower than prevoius study (Val et al. 2012) indicates the lower of PI value, the more efficient the markers (Val et al. 2012). Genetic diversity also assessed by Fis, Fit, and Fst value. According to Soltis and Soltis (1989) the frequency of population genotype deviation could be demonstrated by Fis ranging from -1 (indicate the high heterozygosity) to 1 (indicate the low heterozygosity). Our study demonstrated the higher heterozygosity by value of Fis $(-0.028$ - 1.00) compared with the study of Bakoumé et al. (2014) the Fis value ranging from $0.007-1.00$ for all loci, expressing a deficiency of heterozygosity, indicates deviation from the Hardy-Weinberg equilibrium (HWE), mostly due to inbreeding. Meantime average Fst value in this study (0.383) was higher than Diaz et al. (2014) reported that the Fst value of 311 oil palm tested using 10 microsatellite markers from the Republic of Cameroon was 0.03. The authors also mentioned that Fst value could be associated with the high number of migrants between population. Therefore, 15 groups of oil palm evaluated quietly similarly yet there is a variation among individuals. This variation allows for screening the low lipase activity trait in oil palm, in line with Astari (2016) the higher variation among individuals is potentially for soybean salinity tolerant screening. Average Fit value in this study (0.049) was higher than Arias et al. (2012) the Fit value of populations from the Republic of Cameroon evaluated using 31 microsatellites molecular marker was 0.015 .

\section{Genetic diversity}

The genetic parameters of 15 groups of evaluated oil palm are shown in Tables 3 and 4. A greater value of Ho (observed heterozygosity) indicates that the loci in the population have a high level of heterozygosity while a greater value of $\mathrm{He}$ (expected heterozygosity) indicates a low level of heterozygosity (Govindaraj et al. 2015). In this study, the average observed heterozygosity (Ho) 0.526 was lower than the expected heterozygosity (He) 0.585 , indicating that the genetic diversity was relatively low. Bakoumé et al. (2014) evaluated 49 populations of oil palm using 16 microsatellite markers which resulted in Ho and He means values being 0.46 and 0.64 respectively. Number of allele migration of 15 oil palm groups in this study was 1.429. The number of migration estimates gene flow as many individual genes migrate from one population to the other and per generation $(\mathrm{Nm})$. Its influence is significant in the distribution of genetic materials. $\mathrm{Nm}$ values in this study were 1.43 higher than Budiman et al. (2019), who reported the $\mathrm{Nm}$ value of oil palm from six populations in Cameroon was low (0.41).
Overall, this study identified that the low level of genetic diversity in genotype of oil palm may be due to the breeding program, which agrees with Putri (2010) selfing and selection programs were able to decrease the gene diversity of plants while it is tested on the same markers.

\section{Genetic structure of oil palm}

Genetic structure of this present study was carried out by hierarchical analysis of molecular variance (AMOVA) using the infinite alleles models (F-Statistic) (Purba et al. 2020). The AMOVA of the distance matrix for 15 groups of oil palm leads the overall variation into three levels. The diversity of this population is highly influenced by variation within individuals (54\%), variation among individuals $(31 \%)$, and the lowest variation being among population (15\%) (Table 5). This low value of variation among populations indicates the quite high similarity among 15 groups, supported by Hou and Lou (2011). The higher genetic variation within populations than among populations may partly explain why the northern populations were always clustered together.

Table 3. F-Statistik, total migrant and polymorphic information of population

\begin{tabular}{llrlrrr}
\hline \multicolumn{1}{c}{ Loci } & \multicolumn{1}{c}{ Fis } & Fit & Fst & Nm & PI & PIC \\
\hline mEgCIRLIP_03 & -0.356 & 0.067 & 0.312 & 0.552 & 0.993 & 0.082 \\
mEgCIR_LIP_07 & 1 & 1 & 0.538 & 0.214 & 0.985 & 0.119 \\
DeLEgCIR_C1E3 & -0.028 & 0.279 & 0.88 & 0.588 & 0.990 & 0.097 \\
Mean & 0.205 & 0,449 & 0.383 & 0.452 & - & - \\
SE & 0.408 & 0.282 & 0.078 & 0.119 & - & - \\
\hline
\end{tabular}

Note: Allele frequency correlation between indviduals in subpopulation (Fis), allele frequency correlation between population (Fst), allele frequency in the population caused by Fis and Fst (Fit), total migrants (Nm), Probability Identity (PI), Polymorphic Information Content.

Table 4. Profile of microsatellite loci for 15 groups of oil palm

\begin{tabular}{llccccc} 
Population & & Na & Ne & Ho & He & Nm \\
\hline 15 groups & Mean & 3.178 & 2.970 & 0.526 & 0.585 & 1.429 \\
& SE & 0.197 & 0.185 & 0.065 & 0.033 & - \\
\hline
\end{tabular}

Note Na: number of allele per locus, Ne: number of effective allele; Ho: observed heterozygosity; He: estimated heterozygosity; Nm: number of allele migration.

Table 5. Summary analysis of molecular variance (AMOVA) of 15 groups of oil palm population

\begin{tabular}{lccccc}
\hline Source & df & SS & MS & Est. Var & \% Var \\
\hline Among population & 14 & 42.32 & 3.023 & 0.219 & 15 \\
Among individuals & 30 & 51.2 & 1.711 & 0.461 & 31 \\
Within individuals & 45 & 35.5 & 0.789 & 0.789 & 54 \\
Total & 89 & 129.16 & & 1.469 & 100 \\
\hline
\end{tabular}

Note: df: degree of freedom; SS: Sumsquare; MS: MeanSquare; Est.Var: estimation variation; Var: variant; Fis: inbreeding coefficient; Fit: non-randomating coefficient, Fst: different coefficient 


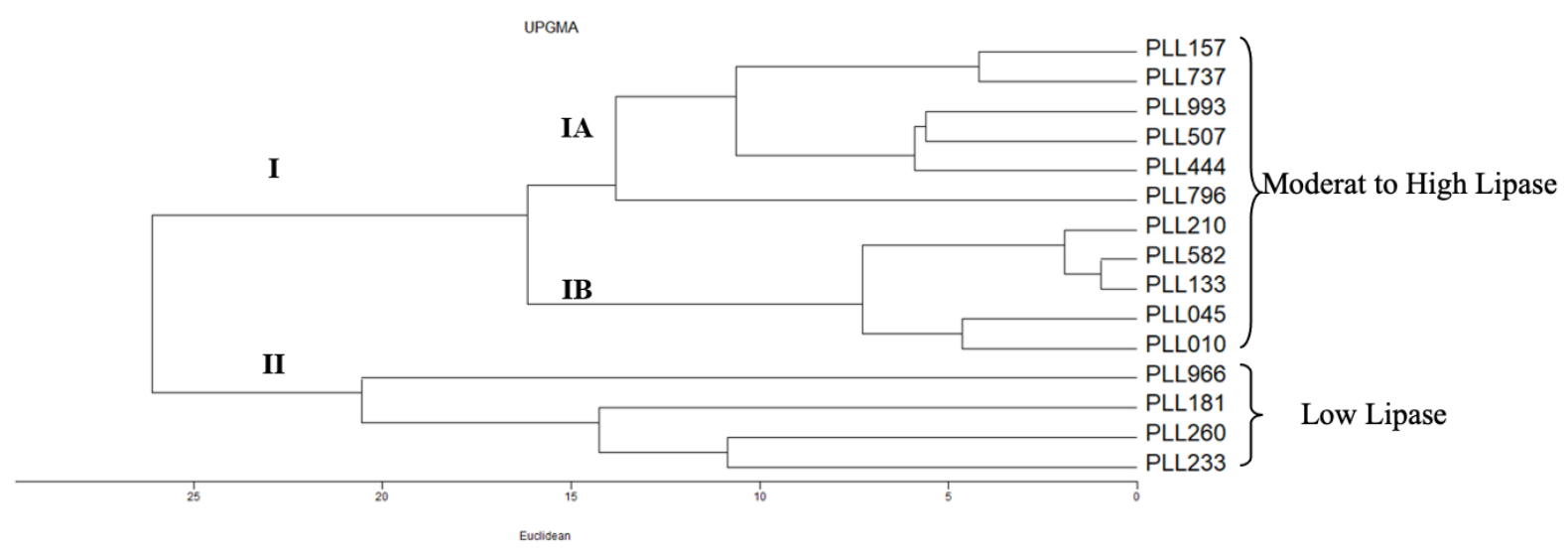

Figure 3. Cluster analysis of 15 groups oil palm based on DNA intensity

\section{Phylogenetic of oil palm groups}

Cluster analysis depicts that there are two main groups in population based on the DNA intensity measurement (Figure 3). The first group consists of 11 groups: PLL157, PLL737, PLL993, PLL507, PLL444, PLL796, PLL210, PLL582, PLL133, PLL045, and PLL010. The second group consists of PLL966, PLL181, PLL260, PLL233, which have lower FFA content. The first group is divided into two sub-clusters. The first cluster IA consists of PLL157, PL737, PLL933, PL507, PL744, and PL796 while the second sub-cluster IB consists of PLL210, PLL582, and PLL133, PLL045, PLL010.

Molecular analysis with 3 validated markers shows compatibility between our study and CIRAD estimate characterization (Table1.) This study analyzes the DNA intensity among 45 genotypes of 15 groups and the resulting four groups in the same clustering were PLL266, PLL230, PLL266, and PLL181, which are estimated as low lipase group by CIRAD. CIRAD estimating of oil palm characterization is based on the crosses of the origin (unpublished data). Val et al. (2012) mention that the membership of olive oil germplasms strongly suggests the existence of common ancestors in the genetic background. Our four selected groups have the same crosses of origin, where DA115D were female parents. Ebongue et al. (2008) evaluated the acidity of oil palm from different origins and it resulted in the progeny from the crosses between LM2T as female parents X DA115D as male parents having higher value of acidity $(24 \%-30 \%)$. In line with our study, Domonhedo et al. (2018) mentions that all offspring of DA115D, from which numerous elite palms used were female parents for seed production originate, were found to be low lipase progenies.

Our study also detected the progenies as high lipase according to CIRAD characterization but only three groups from seven groups they had estimated, such as PLL157, PLL444, and PLL6796. The phylogenetic based on DNA intensity by three markers used show that three groups were in the same cluster. Generally, in our study, the difference between moderate and high lipase groups was not significant. The avarage value of DNA intensity of
DelEgCIR_C1E3 shows that only two characteristics were detected: groups with DNA intensity value higher than average value 247,89 as a high lipase and groups with DNA intensity value lower than average values assumed as low lipase genotype.

However, four groups of oil palm were indicated as an elite low lipase line based on DNA intensity from molecular amplified band. PLL966, PLL181, PLL260, and PLL233 only groups were evident as high lipase according to CIRAD characterization. It was deduced that the lipase activity had low genetic diversity at population level. The most informative markers mEgCIRLIP03 and DelEgCIRC1E3 were relevant to determine two different lipase genotypes for developing oil quality in mesocarp.

\section{ACKNOWLEDGEMENTS}

This study was supported by an Applied Grant (DRPM/2020) No: 11/AMD/E1/KP.PTNBH/2020 on Mei $11^{\text {th }} 2020$ from Directorate for Research and Community Service, Ministry of Research, Technology and Higher Education, Republic of Indonesia.

\section{REFERENCES}

Afandi D, Basyuni M, Putri LAP, Chalil D, Syahputra I. 2018. Expression of oil palm (Elaeis guineensis) polyisoprenoids in response to Ganoderma boninense infection. Biodiversitas 20: 68-76. DOI: 10.13057/biodiv/d200109.

Arias D, Carmenza M, Hernan R. 2012. Molecular characterization of oil palm Elaeis guineensis Jacq. materials from Cameroon. Plant Genetic Resources: Characterization and Utilization. DOI: 10.1017/S1479262112000482.

Astari RP. 2016. Diversity and genetic identification F3 soybean progeny selection based on phenotypes and SSR markers. [Thesis]. Universitas Sumatera Utara, Medan. [Indonesian]

Bakoumé C, Wickneswari R, Siju S, Rajanaidu N, Kushairi A, Billotte N. 2014. Genetic diversity of the world's largest oil palm (Elaeis guineensis Jacq.) field gene bank accessions using microsatellite markers. Genetic Resour Crop Evol 62: 349-360. DOI: 10.1007/s10722-014-0156-8. 
Bariyah K, Nuri A, Purwiyatno H. 2017. Reduction of diglycerides and free fatty acids in crude palm oil using adsorbents. Agritech 37: 4858

Basyuni M, Wati R, Deni I, Tia AR, Siregar ES, Syahputra I. 2018 Cluster analysis of polyisoprenoid in oil palm (Elaeis guineensis) leaves in different land-uses to find the possible cause of yield gap from planting materials. Biodiversitas 19: 1492-1501. DOI: 10.13057/biodiv/d190440.

Bhattacharya S, BandopadhyayTK, Ghosh EPD. 2010. Efficiency of RAPD and ISSR markers in assessment of molecular diversity in elite germplasms of Cymbopogon winterianus across West Bengal, India. J Food Agric 22: 13-24.

Budiman LF, Ardha A, Adi P, Sudarsono S. 2019. Genetic diversity analysis of Tenera $\times$ Tenera and Tenera $\times$ Pisifera Crosses and D self of oil palm (Elaeis guineensis) parental populations originating from Cameroon. Biodiversitas 20: 937-949. DOI 10.13057/biodiv/d200402.

Cardona CCC, Yacenia MC, Ana CMC, Iván O. 2018. Genetic diversity in oil palm (Elaeis guineensis Jacq) using RAM (Random Amplified Microsatellites). Bragantia 77: 546-556. DOI: 10.1590/16784499.2017385.

Corley RHV, Tinker PB. 2016. The Oil Palm. 4th ed. John Wiley \& Sons, Ltd., Oxford.

Diaz JEP, Moreno DMA, Perez ZZO, Angulo HMR. 2014. Diversidad y estructura genética de accesiones de palma de aceite (Elaeis guineesis Jacq.) provenientes de Camerún. Revista Colombiana de Biotecnología 16: 57-67.

Domonhédo H, Cuéllar T, Espeout S, Droc G, Summo M, Rivallan R, Cros D, Nouy B, Omore A, Nodichao L, Arondel F, Ahanhanzo C, Bilotte N. 2018. Genomic structure, QTL mapping, and molecular markers of lipase genes responsible for palm oil acidity in the oil palm (Elaeis guineensis Jacq.). Tree Genet Genome 14: 69. DOI: 10.1007/s11295-018-1284-7.

Ebongue GFN, Koona P, Nouy B, Zok S, Carriere F, Zollo PHA, Aronde V. 2008. Identification of oil palm breeding lines producing oils with low acid values. Eur J Lipid Sci Technol 110: 505-509. DOI: 10.1002/ejlt.200700263.

Ge Y, Tan L, Wu B, Wang T, Zhang T, Chen H, Zhou M, Ma F, Xu Z, Zhan R. 2019. Transcriptome sequencing of different avocado ecotypes: de novo transcriptome assembly, annotation, identification and validation of EST-SSR markers. Forests 10: 411. DOI: 10.3390/f10050411.

Govindaraj M, Vetriventhan M, Srinavasan M. 2015. Review article: Importance of genetic diversity assessment in crop plant and its recent advances: An overview of its analytical perspectives. Genet Res Int 2015: 431487. DOI: 10.1155/2015/431487.

Herrero J, Baitha S, Ana H, Pratiwi E, Upit S, Fahmi W, Zulhermana S, Dwi A, Enrique R. 2010. Construction of a high density linkage map in oil palm using SPET markers. Sci Rep 10: 9998. DOI: $10.1038 / \mathrm{s} 41598-020-67118-y$.

Hou Y, Lou A. 2011. Population genetic diversity and structure of a naturally isolated plant species, Rhodiola dumulosa (Crassulaceae). PLoS ONE 6 (9): e24497. DOI: 10.1371/journal.pone.0024497.

Likeng Li NBC, Bell JM, Ngando EGF, Godswil NN, Ngalle HB. 2016. Genetic determinism of oil acidity among some DELI oil a palm (Elaeis guineesis Jacq.) progenies. Afr J Biotechnol 15: 1841-1845.

Mason AS. 2014. SSR Genotyping Plant Genotyping: Methods and Protocols. Method Mol Biol 1245: 77-89. DOI: 10.1007/978-1-49391966-66.

Morcillo F, Cros D, Bilotte N, Ngando-Ebongue GF, Domonhédo H, Pizot M, Cuéllar T, Espéout S, Dhouib R, Bourgis F, Claverol S, Tranbarger TJ, Nouy B, Arondel V. 2013. Improving palm oil quality through identification and mapping of the lipase gene causing oil deterioration. Nat Commun 4: 2160 DOI: 10.1038/ncomms3160.

National Standardization Bodies of Indonesia. 2006. Crude Palm Oil SNI 01-2901-2006
Nei M, Chesser RK. 1983. Estimation of fixation indices and gene diversities. Ann Hum Genet 47 (3): 253-259. DOI: 10.1111/j.14691809.1983.tb00993.x.

Nurniwalis AW. 2017. Physiological, Biochemical and Molecular Analyses of Fruit Development in Oil Palm (Elaeis guineensis Jacq.). [Dissertation]. University of Nottingham Malaysia, Selangor.

Oettli P, Behera SK, Yamagata T. Climate based predictability of oil palm tree yield in Malaysia. Sci Rep. DOI: 10.1038/s41598-018- 20298-0

Okoye M, Uguru MI, Bakoume C, Singh R, Okwuagwu CO. 2016. Assessment of genetic diversity of NIFOR oil palm main breeding parent genotypes using microsatellite markers. Am J Plant Sci 7: 218237.

Orozco-Castillo K, J Chalmers, R Waugh, W Powell. 1994. Detection of genetic diversity and selective gene introgression in coffee using RAPD markers. Theoret Appl Genet 87: 934-940. DOI: 10.1007/BF00225787

Peakall, Smouse. 2012. Introduction to population genetic analysis. GenAlex Genetic Analysis in Excel. Based on material provided at the national graduate workshop An Introduction to Genetic Analysis for Populations Studies offered by Rod Peakall and Peter Smouse at the Australian National University, Canberra, Australia.

Purba A, Hayati H, Putri LAP, Chalil D, Afandi D, Syahputra I, Basyuni M. 2020. Genetic diversity and structure of Ganoderma boninense isolate from oil palm and other plantation crops. Biodiversitas 21 (2): 451-456. DOI: 10.13057/biodiv/d210204.

Putri LAP. 2010. Estimation of Genetic Parameters and Molecular Characterization of Genetic Diversity Using Microsatellite (SSR) Markers on Oil Palm. [Thesis]. IPB University, Bogor, Indonesia. [Indonesian]

Roubos K, Moustakas M, Aravanopoulos FA. 2010. Molecular identification of Greek olive (Olea europaea) based on microsatellite loci. Genet Mol Res 9 (3): 1865-1876. DOI: 10.4238/vol9-3gmr916.

Sambanthamurthi, Kushairi A. 2002. Selection for Lipase Activity in Oil Palm. Malaysian Palm Oil Board, Ministry of Primary Industries, Malaysia. MPOB TT 41. http://palmoilis.mpob.gov.my.

Sarimana U, Nurcahyono I, Javier H, Pratiwi E, Fahmi W, Zulhermana Z, Dwi A. 2019. Genetic diversity preliminary study of Cameroon origin oil palm at PT. Binasawit Makmur. J Suboptimal Lands 8: 130. DOI: 10.33230/JLSO.8.2.2019.424

Sharif ZBM, Taib NBM, Yusof MSB, Rahim MZ Bin, Tobi ALBM, Othman MS Bin. 2017. Study on handing process and quality degradation of oil palm fresh fruit bunches (FFB). IOP Conf Ser Mater Sci Eng 203: 012027. DOI:10.1088/1757-899X/203/1/012027.

Singh SP, Jignasha, Thumar JT, Gohel SD, Kikani B, Shukla R, Sharma A and Dangar K. 2013. Actinomycetes from marine habitats and their enzymatic potential. In: Marine Enzyme Biocatalysis. Woodhead Publishing Limited, UK. DOI: 10.1533/9781908818355.2.191

Soltis DE, Soltis PS. 1989. Polyploidy, breeding system and genetic differentiation in homosporous pteridophytes. In: Soltis DS, Soltis PS (eds). Isozymes in Plant Biology. Dioscorides Press, Portland.

Thongthawee S, Tittinutchanon P, Volkaert H. 2010. Microsatellites for parentage analysis in an oil palm breeding population. Thai J Genet 3 (2): 172-181

Val ADB, Ferreira J, Veira N, Pasqual M, de Oleiveira AF, Boren A, Cancado GMA. 2012. Genetic diversity of Brazilian and introduced olive germplasm based on microsatellite markers. Genet Mol Res 11 (1): 556-571. DOI: 10.4238/2012.March.8.4

Wong YT, Kushairi A, Rajanaidu N, Osman M, Wicknesmwari R, Sambhanthamurti R. 2015. Screening of wild oil palm (Elaeis guineensis) germplasm for lipase activity. J Agric Sci. DOI: $10.1017 / \mathrm{S} 0021859615001112$.

Yoichi W, Sakaguchi S, Ueno S, Tomaru N, Uehara K. 2016. Development and characterization of EST log SR markers for the genus Rhododendron section Brachycalyx (Ericaceae). Plant Spec Biol 32: 455-459. DOI: 10.1111/1442-1984.12155. 